\title{
Impact of Internet on Students and Lecturers in Nigeria Higher Institutions of Learning
}

\author{
Dr. Ijeoma P.Eze*, Dr. Sunday Aja Nwambam \\ Department of Educational Foundations, Faculty of Education, Ebonyi State University, Abaklaiki, Nigeria \\ *Corresponding Author: Dr. Ijeoma P.Eze, Department of Educational Foundations, Faculty of \\ Education, Ebonyi State University, Abaklaiki, Nigeria
}

\begin{abstract}
The study investigated the impact of the internet on carrying academic activities in higher institutions of learning in Ebonyi State, Nigeria. The study adopted survey research design. Data were collected with questionnaire and interviews. The population of the study comprises of all the students and lecturers in Ebonyi State higher institutions of learning. Purposeful sampling technique was used to select 250 respondents for the study. Data collected were analysed using mean scores. The study found that internet has positive impact on students' performance in assignment and research project as well as lecturers' lecture notes and research activities. Recommendations include: that higher educational institutions should ensure that adequate internet services are provided in their libraries to students and lecturers effective use.
\end{abstract}

Keywords: Internet; Academic Activities, Higher Education, Teaching and Learning

\section{INTRODUCTION}

In human history and civilization, there continue to be a shift in the modes and means of improving the quality and products of education. With the industrial and technical advancement, sophisticated scientific technological devices, instruments, mass media and educational material such as radio, television, computer, video tape, PowerPoint, internet and host of others has become means of instructional delivery. It is a well-known fact that education whether formal or informal is goaloriented and instrument for national development. It prepares students be relevant for global competitiveness to meet international standard. By implication, it must be functional, qualitative and socio-personal driven. Socio-personal in the sense that it must be tailored towards serving the society and individuals involved. The current global application of technological devices such as internet in teaching and learning has been receiving approvals from students, teachers, educationists and scholars for its positive contributions to educational sector as it solves educational problems by providing information to teachers and students no matter the time and place. Apparently, this brings about reduction in the cost of information delivery to users in the education system. But there is mixed feelings as to whether the way lecturers and students are using internet in Higher Institutions of learning will equip them with the right type of knowledge, skills and competences to compete with their counter parts in the labour market in order to contribute their quota in developing their nations and solving their persona-social problems after graduation. This accounts for why the researcher intends to assess the impact of internet use on the academic activities.

\subsection{Literature Review}

Internet is popularly referred to as net. It is a system of communication on a global basis. According to Mangal and Mangal (2014), internet is known as the largest wide area network (WAN) in the world. It is the largest inter-network system (the network of networks) that provides the fastest, easiest and cheapest means for the countless users to get, provide and communicate information on a global basis. Internet is a complex of interconnected computer networking worldwide which is available for use to the general public. These interlinked computers transmit data through a special communication protocols called internet protocol (IP) (Wikipedia, 2018) internet hold wide range of information resources and services which are used for different purposes like transfer of files, sharing documents chatting online and many more. The impact of internet on education can be felt in homes, schools, colleges, universities, with information available at a check of bottom. Use of internet in education makes access to large academic information easier. The graphic and animations concomitant to 
internet make the study of learning materials much more interesting than those of traditional books. Teachers also find it easy to assess and track the progress of their students as well as embark on extensive research through the use of internet. It is also a proven fact that internet enhances the educational process by braining the classroom, students and teacher one platform irrespective of gender, race, age, religion, geographic location or disability (authors). The internet is a potential medium for processing, retrieving and disseminating information with positive impacts on students and scholars globally. it has been identified as in separable companion in today's educational system for the increasing dependence of academic activities on the internet. Many higher institution of learning around the world are investing heavily on information technology especially the internet for efficient e-learning. The use of the internet for learning is a means to improve accessibility, efficiency and quality of learning by facilitation access to resources and service exchanges and collaboration. The internet has become a valuable tool for learning, teaching and research (including collaborative research) in Nigeria (Nwokedi, 2007) in Oghenetega and Igere (2014). Ogedebe (2012) in his study found that $79 \%$ of the respondents accepted that their academic performance has been improved by using the internet, while $13 \%$ believed otherwise, $8 \%$ made no response to that question. The study also revealed that $65 \%$ of the respondents were computer literate, while $29 \%$ were not, $6 \%$ of the respondents neglected the question. The study further revealed that $8 \%$ of the respondents believed that their GPA has been improve remarkably as a result of the internet, 6\% agreed that their GPA has been declining, 28\% responded that it aids them in preparing better for CA and semester examination while $22 \%$ were indifferent about the options and therefore did not respond. In the study of Agil and Ahmad (2011) it was found that 47(52.64\%) users rated the utility of internet based information services as average for their academic purposes, while $36(39.56 \%)$ users rated the internet as high. Moreover, $6(6.59 \%)$ and $2(2.19 \%)$ rated it as low and very low respectively. They noted that the World Wide Web service provided by the internet with over. 5 million web sites allows students from all disciplines to source for relevant academic information. Gudimani and Mulimani (2008) in Oghenetega and Igere (2014) observed that majority of the student and lecturers. Use the internet for online database electronic journals, other internet web based materials, published files.

Udende and Azeez (2010) reported that 3.11 (80.8\%) of students of the University Illorin, admitted that they mostly use the internet for academic purpose, while 54(14\%) used it mostly for mails, $19(4.9 \%)$ used it most for fun, none for others. 100 (26\%) of the respondents agreed that they used the internet daily, 178(46.2\%) used the internet on weekly basis, while 107(27.8) used the facility ones in a while. The study also revealed that $38(9.9 \%)$ respondents were of the opinion theat the internet does not contribute towards their academic excellence, whereas as many as $347(90.1 \%)$ held a contrary view that the internet help them in solving their academic problems. Oghenetega and Igere (2014) noted that majority of students in Nigeria tertiary institution use the internet in order to retrieve relevant better for their examinations and other academic activities. Academic activities are those programmes that fall under the realm of the normal curriculum of school or institutions of learning perform by students and teachers under the auspices of the school. Academic activities in the context of this paper are those exercises that are related to teaching and learning which are carried out in the Higher Institutions of learning such as classroom teaching and learning, quizzes take home assignments, classroom tests, seminar works, project works, lectures and so on. Institutions refers to higher education is offered to students after their secondary school education. They include universities, polytechnics, colleges of technology, and colleges of education, correspondence colleges and such institution that may be allied to them (FRN, 2013). Higher education in Nigeria aims at:

- The acquisition, development and inculcation of proper, value orientation for survival of the individual and society.

- The development of the intellectual capacities of individuals to understand and appreciate their environments;

- The acquisition of both physical and intellectual skills which will enable individuals to develop into useful members of the community.

- The acquisition of an objective new of the local and external environments. Higher educational institutions achieve these goals community service and acting as a storehouse of knowledge. It is the intention of Nigeria government that a greater proportion of higher education expenditure will be devoted to science and technology which the internet takes the centre stage hence the need for this study. 


\subsection{Statement of Problem}

Exchange of information, ideas, skills, values, can be done through many means or channels such as internet. Internet is known as a tool for storing, processing, transferring and receiving of information. It has brought a great success into the education system world over as it seems to be one of the most efficient source of information. Notwithstanding, the benefit of internet depends much on how internet is used by lecturers and students in teaching and learning especially in higher institutions where teaching and learning is more technology oriented. There is speculations that the use of internet in sourcing and disseminating information will impair the quality education as some users of internets are not interested in applying their own initiatives to the internet materials sourced out rather, they just lift other peoples' work and claim them as their own. This necessitates the problem of the study: Impact internet use on academic activities in Higher Institutions of learning.

\subsection{Scope of the Study}

This study centred on the assessment of internet use on academic activities in Higher Institutions of learning. Lecturers in higher institutions in Ebonyi State, Nigeria, constituted the sample. The study determined the impacts of internet on students take home assignment, research work and lecturers' work.

\subsection{Purpose of the Study}

The general purpose of the study is to find out the use of internet on academic activities in Higher Institutions of learning. Specifically, the study sought to:

- Ascertain the impacts of internet use students in carrying research project.

- Determine the impacts of internet use on students in carrying research project

- Examine the impacts of internet use on lecturer's academic activities in institutions of higher learning.

\subsection{Research Questions}

- How does the use of internet impact on students in carrying class assignment?

- In what ways does the use of internet impact on students in carrying research projects?

- How does the use of internet impact lecturers' academic activities in institutions of higher learning.

\section{Methodology}

The design of the study is a descriptive survey research design. The study was carried out in Ebonyi State public Higher Institutions of learning. Ebonyi State has six Higher Institutions of learning. They are: Ebonyi State University, Abakaliki, Federal University Ndufu Alike Ikwo, Akunu Ibiam Federal Polytechnic, Unwana and College of Agriculture Ishiagu. Ebonyi State tertiary institution was used for the study because of its reliance on research in disseminating is working existing and new knowledge. The population of the study comprised all the student and lecturers in the institutions of higher learning in Ebonyi State, Nigeria which induces: Ebonyi State University (EBSU), federal University Ndufu Alike Ikwo, (FUNAI) Ebonyi State college of Education, Akanu Ibiam Federal Polytechnic, Unwana and College of Agriculture Ishiagu Total 250 respondents used for the study. The comprised of 50 lecturers and 200 students. Ten(10 lecturers and forty (40) students were selected from each of the 5 institutions through purposeful sampling technique researchers structured questionnaire was developed on internet use on Academic activities in higher institutions of learning". (IUAAHILQ). The questionnaire contains twenty two (22) item statements in all. The instrument had four point rating scale of strongly agree (AS),-4 points, agree (A)-3 points, low Disagree (D)-2points, strongly Disagree (SD)1point. The draft instrument (AIUAATILQ) was presented to three experts, one from educational administration one from educational technology and one from educational measurement and evaluation. The experts were asked to determine whether the items are clear and unambiguous. The comments from these experts were used to produce the final version of the questionnaire.

The reliability of the instrument was determined using SPSS package. The scores obtained from trial testing, on lecturers of college of health technology Ezzamgbo higher institution of learning, which was not one of the institution sampled for the study was used to establish the internal consistency reliability coefficient. A coefficient value of 0.71 was got. The value is high enough to consider the 
instrument suitable for the study. The instrument was administered to the respondents by the researchers. Five research assistants, one from each institution were briefed on how to administer and collect the questionnaire the entire questionnaire administered were collected back. The data collected was analysed using mean scores. In order to arrive at decision, 2.50 were adopted as the bench mark. It was obtained by adding the nominal values of the rating scale and the summation was divided by the number. Thus: $4+3+2+1=10 / 4=2.50$. Therefore, any mean from 2.5 and above is adjudged as agree while any score below 2.5 is regarded as disagree. The response option is presented in a four point rating scale thus: Strongly Agree (SA)- 4points, Agree (A)- 3points, Disagree (D)- 2points, and Strongly Disagree (SD)- 1point.

\section{Results}

Interpretation of keys: $\mathrm{N}=$ number of respondents; $\mathrm{fx}=$ Frequency response; $\bar{X}=$ Mean.

\subsection{Research Question One: How Does the Use of Internet Impact on Students in Carrying Class Assignment?}

Mean response of respondents on the imparts of internet on students in carrying class assignment

\begin{tabular}{|c|c|c|c|c|c|c|c|c|c|}
\hline $\mathbf{S} / \mathbf{N}$ & Item statement & $\mathbf{S A}$ & $\mathbf{A}$ & $\mathbf{D}$ & SD & $\mathbf{N}$ & FX & $\bar{X}$ & Decision \\
\hline 1 & $\begin{array}{l}\text { Internet use makes students to have confidence } \\
\text { in themselves in solving class assignment. }\end{array}$ & $\begin{array}{l}400 \\
120\end{array}$ & $\begin{array}{l}330 \\
110\end{array}$ & $\begin{array}{l}50 \\
25\end{array}$ & $\begin{array}{l}15 \\
15\end{array}$ & 250 & 795 & 3.18 & Agree \\
\hline 2 & $\begin{array}{l}\text { Internet use encourages students independence } \\
\text { in carrying class assignments. }\end{array}$ & $\begin{array}{l}440 \\
110\end{array}$ & $\begin{array}{l}300 \\
110\end{array}$ & $\begin{array}{l}50 \\
15\end{array}$ & $\begin{array}{l}25 \\
25\end{array}$ & 250 & 795 & 3.18 & Agree \\
\hline 3 & $\begin{array}{l}\text { Internet use assists students carrying their class } \\
\text { assignment faster. }\end{array}$ & $\begin{array}{l}460 \\
115\end{array}$ & $\begin{array}{l}300 \\
100\end{array}$ & $\begin{array}{l}50 \\
15\end{array}$ & $\begin{array}{l}10 \\
10\end{array}$ & 250 & 800 & 3.2 & Agree \\
\hline 4 & $\begin{array}{l}\text { Use of internet in carrying class assignments } \\
\text { increases critical thinking among students. }\end{array}$ & $\begin{array}{l}400 \\
100\end{array}$ & $\begin{array}{l}270 \\
90\end{array}$ & $\begin{array}{l}12 \\
60\end{array}$ & 0 & 250 & 790 & 3.16 & Agree \\
\hline 5 & $\begin{array}{l}\text { Use of internet encourages students team } \\
\text { work in solving their class assignment. }\end{array}$ & $\begin{array}{l}120 \\
180\end{array}$ & $\begin{array}{l}85 \\
255\end{array}$ & $\begin{array}{l}30 \\
60\end{array}$ & $\begin{array}{l}15 \\
15\end{array}$ & 25 & 810 & 3.14 & Agree \\
\hline 6 & $\begin{array}{l}\text { Use of internet makes student to be on top of } \\
\text { their class assignments }\end{array}$ & $\begin{array}{l}150 \\
600\end{array}$ & $\begin{array}{l}90 \\
270\end{array}$ & $\begin{array}{l}10 \\
20\end{array}$ & 0 & 250 & 890 & 3.56 & Agree \\
\hline 7 & $\begin{array}{l}\text { Internet helps students to carry their class } \\
\text { assignment at their convenient time. }\end{array}$ & $\begin{array}{l}120 \\
480 \\
\end{array}$ & $\begin{array}{l}100 \\
300 \\
\end{array}$ & $\begin{array}{l}20 \\
40 \\
\end{array}$ & $\begin{array}{l}10 \\
10 \\
\end{array}$ & 250 & 830 & 3.32 & Agree \\
\hline & Grand mean & & & & & & & 3.26 & \\
\hline
\end{tabular}

The result of the data analysed in table one shows that the respondents agreed items 1-7. This implies that internet impact positively on students in carrying their class assignments as shown by the grand mean of 3.26 .

\subsection{Research Question Two: In What Ways Does the Use of Internet Affects Students in their Research Work?}

Mean response of respondents on the imparts of internet on students their research work

\begin{tabular}{|c|c|c|c|c|c|c|c|c|c|}
\hline $\mathbf{S} / \mathbf{N}$ & Item statement & SA & A & $\mathrm{D}$ & SD & $\mathrm{N}$ & FX & $\bar{X}$ & Decision \\
\hline 8 & $\begin{array}{l}\text { Use of internet helps students to improve } \\
\text { the grammar in their research work. }\end{array}$ & $\begin{array}{l}110 \\
440\end{array}$ & $\begin{array}{l}90 \\
270\end{array}$ & $\begin{array}{l}30 \\
60\end{array}$ & $\begin{array}{l}20 \\
20\end{array}$ & 250 & 790 & 3.16 & Agree \\
\hline 9 & $\begin{array}{l}\text { Students are exposed to current research } \\
\text { materials through the internet. }\end{array}$ & $\begin{array}{l}120 \\
480\end{array}$ & $\begin{array}{l}100 \\
300\end{array}$ & $\begin{array}{l}20 \\
40\end{array}$ & $\begin{array}{l}10 \\
10\end{array}$ & 250 & 830 & 3.32 & Agree \\
\hline 10 & $\begin{array}{l}\text { Internet makes writing of project easier } \\
\text { for students. }\end{array}$ & $\begin{array}{l}115 \\
460\end{array}$ & $\begin{array}{l}105 \\
315\end{array}$ & $\begin{array}{l}25 \\
50\end{array}$ & $\begin{array}{l}05 \\
5\end{array}$ & 250 & 830 & 3.32 & Agree \\
\hline 11 & $\begin{array}{l}\text { Use of internet encourages global } \\
\text { competitiveness among students research. }\end{array}$ & $\begin{array}{l}75 \\
300 \\
\end{array}$ & $\begin{array}{l}55 \\
165 \\
\end{array}$ & $\begin{array}{l}80 \\
160 \\
\end{array}$ & $\begin{array}{l}40 \\
40 \\
\end{array}$ & 250 & 665 & 2.66 & Agree \\
\hline 12 & $\begin{array}{l}\text { Internet information helps students to } \\
\text { access funds for research projects. }\end{array}$ & $\begin{array}{l}50 \\
200 \\
\end{array}$ & $\begin{array}{l}70 \\
210 \\
\end{array}$ & $\begin{array}{l}80 \\
160 \\
\end{array}$ & $\begin{array}{l}50 \\
50\end{array}$ & 250 & 640 & 2.48 & Disagree \\
\hline 13 & $\begin{array}{l}\text { Students have access to as many scholars } \\
\text { work, as much as possible than the use of } \\
\text { conventional library }\end{array}$ & $\begin{array}{l}100 \\
400\end{array}$ & $\begin{array}{l}105 \\
315\end{array}$ & $\begin{array}{l}40 \\
80\end{array}$ & $\begin{array}{l}5 \\
5\end{array}$ & 250 & 800 & 3.2 & Agree \\
\hline 14 & $\begin{array}{l}\text { Internet use emphasizes the locality of } \\
\text { most students' research work. }\end{array}$ & $\begin{array}{l}90 \\
360\end{array}$ & $\begin{array}{l}100 \\
300\end{array}$ & $\begin{array}{l}50 \\
100\end{array}$ & $\begin{array}{l}10 \\
10\end{array}$ & 250 & 770 & 3.08 & Agree \\
\hline 15 & $\begin{array}{l}\text { Time of research work is reduced } \\
\text { through the use of internet facilities. }\end{array}$ & $\begin{array}{l}80 \\
320\end{array}$ & $\begin{array}{l}90 \\
270\end{array}$ & $\begin{array}{l}60 \\
120\end{array}$ & $\begin{array}{l}20 \\
20\end{array}$ & 250 & 730 & 2.92 & Agree \\
\hline & Grand mean & & & & & & & 3.02 & \\
\hline
\end{tabular}


Table two data analysis reveal that the respondents agreed on item $8,9,10,11,13,14$ and 15 but disagreed on item 12. However, the overall grand mean of 3.02 is indicative that the internet positively impact on students in carrying out research projects.

\subsection{Research Question Three: How Does the Use of Internet Impact on Lecturers' in Carrying Out Academic Activities in Higher Institution?}

\begin{tabular}{|c|c|c|c|c|c|c|c|c|c|}
\hline $\mathbf{S} / \mathbf{N}$ & Item statement & SA & A & $\mathrm{D}$ & SD & $\mathrm{N}$ & $\mathrm{FX}$ & $\bar{X}$ & Decision \\
\hline 16 & $\begin{array}{l}\text { Use of the internet helps lecturers to } \\
\text { deliver lectures without necessarily being } \\
\text { in lecturer classes. }\end{array}$ & $\begin{array}{l}100 \\
400\end{array}$ & $\begin{array}{l}120 \\
360\end{array}$ & $\begin{array}{l}30 \\
60\end{array}$ & 0 & 250 & 820 & 3.28 & Agree \\
\hline 17 & $\begin{array}{l}\text { Internet helps lecturers source lecturers } \\
\text { source lecture materials from many } \\
\text { sources easily. }\end{array}$ & $\begin{array}{l}120 \\
480\end{array}$ & $\begin{array}{l}100 \\
300\end{array}$ & $\begin{array}{l}20 \\
40\end{array}$ & $\begin{array}{l}10 \\
10\end{array}$ & 250 & 830 & 3.32 & Agree \\
\hline 18 & $\begin{array}{l}\text { Use of the internet encouragement } \\
\text { qualitative research through collaboration } \\
\text { among lecturers. }\end{array}$ & $\begin{array}{l}70 \\
280\end{array}$ & $\begin{array}{l}100 \\
30\end{array}$ & $\begin{array}{l}80 \\
160\end{array}$ & $\begin{array}{l}50 \\
50\end{array}$ & 250 & 790 & 3.16 & Agree \\
\hline 19 & $\begin{array}{l}\text { Lecturers share their research works } \\
\text { globally through the internet. }\end{array}$ & $\begin{array}{l}80 \\
320\end{array}$ & $\begin{array}{l}100 \\
300\end{array}$ & $\begin{array}{l}50 \\
100\end{array}$ & $\begin{array}{l}20 \\
20\end{array}$ & 250 & 730 & 2.92 & Agree \\
\hline 20 & $\begin{array}{l}\text { Internet provides information on how to } \\
\text { access research funds by lecturers. }\end{array}$ & $\begin{array}{l}50 \\
200\end{array}$ & $\begin{array}{l}70 \\
210\end{array}$ & $\begin{array}{l}100 \\
200\end{array}$ & $\begin{array}{l}30 \\
30\end{array}$ & 250 & 640 & 2.56 & Agree \\
\hline 21 & $\begin{array}{l}\text { Information got from the internet mails } \\
\text { lecturers scholarship opportunities. }\end{array}$ & $\begin{array}{l}60 \\
24\end{array}$ & $\begin{array}{l}80 \\
240\end{array}$ & $\begin{array}{l}70 \\
140\end{array}$ & $\begin{array}{l}40 \\
40\end{array}$ & 250 & 660 & 2.64 & Agree \\
\hline 22 & $\begin{array}{l}\text { Internet provides easier platform for } \\
\text { lecturer to publish online. }\end{array}$ & $\begin{array}{l}90 \\
360\end{array}$ & $\begin{array}{l}100 \\
300\end{array}$ & $\begin{array}{l}50 \\
100\end{array}$ & $\begin{array}{l}10 \\
10\end{array}$ & 250 & 770 & 3.08 & Agree \\
\hline & Grand mean & & & & & & & 2.99 & Agree \\
\hline
\end{tabular}

Data analysis in table three indicates that the respondents agreed on items 16-22. This shows that the internet positively impact on lecturers in carrying out their academic activities as shown by the grand mean of 2.99 .

\section{DISCUSSION OF THE FINDINGS}

On the impacts of internet in carrying out academic activities by students and lecturers in higher educational institutions, the result of data analysed in table four reveals that the internet makes students to have confidence in them, encourage students' independence and increases critical thinking among students. The use of internet also makes it easier and faster for students to carry out assignments as well as ensure convenience as students tend to be in full control of their assignment. The use of internet shows that it encourages teamwork among students. The findings are supported by Udende an Azeez (2010), Aquil and Ahmad (2011) Ogedebe (2012) and Ogenetega and Igere (2014).

On ways the use of the internet impact on students in carrying research projects. The results in table two shows that internet helps student to improve the grammar in their research work as it exposes students to current research materials. Internet makes writing of project easier for students as it gives them access to many scholarly works more than the use of conventional book library. Internet encourages global competitiveness of students' research as it de-emphasizes the locality of research work in time and space. However, the result is evident that internet information does not help students to access funds for their research projects. This is corroborated by Okebukola (2005) who observed that the inability to extent the use of internet to teaching and research especially in the higher educational institutions in Nigeria has negatively, impacted on the quality of graduates, research project when compared with graduates from schools in the developed countries with functional elearning tradition that gives students easy access source of fund for research.

On how the use of the internet impacts on lecturers in carrying academic activities in higher educational institutions, the result indicates that the use of the internet helps lecturers to deliver their lectures without necessarily being in the class. Internet helps source and prepare lecture/research materials easily, internet encourage research collaboration among lecturers as they exchange or share research work globally through the internet. Internet also provides information on how to access research funds and scholarship opportunities by lecturers as well as provide easier platform for lecturers to publish online. It is in support of these findings that Jagboro (2003), Yusuf (2005) and Okorie, Agabi and Uche (2005) noted that the inability of Nigerian lecturers to use the internet for teaching and research seemingly makes them ignorant of teaching and research innovations. 


\section{CONCLUSION AND RECOMMENDATIONS}

The use of internet has opened gateway to new ways of teaching and learning. The use of internet for academic purpose occupies the highest position as far as students and lecturers are concerned. In order to ensure effective utilization of the internet by students and lecturers in higher educational institutions, these institutions should acquire standby generators to forestall the problem of incessant power outage. Also higher educational institutions should ensure that adequate internet services are provided in their libraries to students and lecturers effective use. Above all, more technical staff should be deployed in higher education institution to provide expert assistance to students and lecturers as well as ensure regular maintenance of internet facilities.

\section{REFERENCES}

[1] Agil, M. Ahmad, P. (2011). Use of the internet by research scholars and post graduate students of Aligart Muslim University. Retrieved on 14 feb, 2018 from http:/.unllib/uni.edu/lppl

[2] Jagboro, K.O. (2003). A study of internet usage in Nigerian universities: A case study of Obafemi Awolowo Universities, Ile-Ife. Journal of educational computing research 22(4): 383-395.

[3] Mangal, S.K. and Mangal, U. (2014). Essentials of educational technology. Delhi: Phi learning private limited.

[4] Nworgu, B. (2006). Educational research. Ibadan: wisdom publishers

[5] Ogedebe, P.M. (2012). Internet usage and students academic performance in Nigeria tertiary institution: a case study of university of Maiduguri. Academic research (2(3): 1-10.

[6] Oghenetega, I. and Igere, M.A. (2014). Impact of the internet on the academics performance of student in Higher Institutions in Nigeria. Journal of information and knowledge management 5(2): 47-56.

[7] Okebukola, P. (2005). The state of university education in Nigeria. Abuja: National university commission.

[8] Okorie, D.N.; Agabi, B. and Uche, G.B. (2005). Application of information and communication technology in the management of public and private universities. Nigerian journal of educational administration and planning 5(2): 29-38.

[9] Udende, P. and Azeez, A.L. (2010). Internet access and use among students of the University of Illorin, Nigeria. Journal of communication and media research 2(1): 33-42.

[10] Wikipedia (2018). Internet definition and meaning. Retrieved on $15^{\text {th }}$ February, 2018 at https://en. mwikipedia.orgwiki/internet

[11] Yusuf, M.O. (2005). Information and communication technology: Analyzing the Nigerian national policy for information. International education journal 6(3): 316-321.

\section{AUTHORS' BIOGRAPHY}

Aja Sunday Nwambam holds a Bachelor Degree in Guidance and Counseling, Master Degree and a $\mathrm{PhD}$ in Educational Administration and Planning. Research interests are human resource development, Teachers professional growth and educational policy analysis. He is currently a senior lecturer in the Department of Educational Foundations Ebonyi State University Abakaliki Nigeria.

Dr. Eze Ijeoma Prisca holds a Bachelor Degree in Education Social studies/ Religion, Master Degree and a $\mathrm{PhD}$ in Educational Technology. Research interests are human resource development and educational media development. He is currently a senior lecturer in the Department of Educational Foundations Ebonyi State University Abakaliki Nigeria.

Citation: Dr. Ijeoma P.Eze, Dr. Sunday Aja Nwambam "Impact of Internet on Students and Lecturers in Nigeria Higher Institutions of Learning". International Journal of Humanities Social Sciences and Education (IJHSSE), vol. 6, no.6, 2019, pp. 14-19. doi: http://dx.doi.org/10.20431/2349-0381.0606002.

Copyright: (C) 2019 Authors. This is an open-access article distributed under the terms of the Creative Commons Attribution License, which permits unrestricted use, distribution, and reproduction in any medium, provided the original author and source are credited. 